\title{
Antioxidant capacity and biological activity of essential oil and methanol extract of Hyptis crenata Pohl ex Benth
}

\author{
Monaliza M. Rebelo, ${ }^{1}$ Joyce Kelly R. da Silva, ${ }^{2}$ Eloísa Helena A. Andrade, ${ }^{3}$ \\ José Guilherme S. Maia *,3
}

\begin{abstract}
'Programa de Pós-Graduação em Ciências e Tecnologia de Alimentos, Universidade Federal do Pará, 66075-900 Belém-PA, Brazil,

${ }^{2}$ Programa de Pós-Graduação em Química, Universidade Federal do Pará, 66075-900 Belém-PA, Brazil, ${ }^{3}$ Faculdade de Engenharia Química, Universidade Federal do Pará, 66075-900 Belém-PA, Brazil
\end{abstract}

\begin{abstract}
RESUMO: “Capacidade antioxidante e atividade biológica do óleo essencial e extrato metanólico de Hyptis crenata Pohl ex Benth". O óleo essencial das folhas e ramos finos frescos e secos de Hyptis crenata forneceu os seguintes rendimentos, 1,4\% e $0,9 \%$. Os constituintes voláteis principais foram $\alpha$-pineno $(22,0 \% ; 19,5 \%), 1,8$-cineol $(17,6 \% ; 23,2 \%), \beta$-pineno $(17,0 \%$ : $13,8 \%)$, cânfora $(4,7 \% ; 11,6 \%)$, limoneno $(5,4 \% ; 4,4 \%)$ e $\gamma$-terpineno $(3,5 \% ; 2,4 \%)$, totalizando mais de $70 \%$ nos óleos. A atividade de seqüestro do radical DPPH para o extrato metanólico $\left(\mathrm{CE}_{50}, 16,7 \pm 0,4 \mu \mathrm{g} / \mathrm{mL}\right)$ foi comparável ao do BHT $(19,8 \pm 0,5 \mu \mathrm{g} / \mathrm{mL})$ mostrando uma significante atividade antioxidante. Os óleos apresentaram baixa atividade. $\mathrm{O}$ teor de fenólicos totais (TP, 373,0 $\pm 15,9 \mathrm{mg} \mathrm{GAE} / \mathrm{g}$ ) e equivalente trolox (TEAC, 226,8 \pm 0,5 mg TE/g) confirmaram a atividade antioxidante do extrato metanólico, que pode ser atribuída à presença de compostos fenólicos polares. No teste com larvas de camarão as concentrações letais para o óleo e extrato metanólico foram $6,7 \pm 0,2 \mu \mathrm{g} / \mathrm{mL}$ e $13,0 \pm 3,7 \mu \mathrm{g} / \mathrm{mL}$, respectivamente, fornecendo importante evidência de suas atividade biológicas.
\end{abstract}

Unitermos: Hyptis crenata, Lamiaceae, "salva-do-marajó", óleo essencial, atividade antioxidante, teor de fenólicos totais, citotoxidade.

\begin{abstract}
The essential oils of fresh and dried leaves and fine stems of Hyptis crenata furnished the following yields: $1.4 \%$ and $0.9 \%$. The main volatile constituents were $\alpha$-pinene $(22.0 \% ; 19.5 \%), 1,8$-cineole $(17.6 \% ; 23.2 \%), \beta$-pinene $(17.0 \% ; 13.8 \%)$, camphor $(4.7 \%$; $11.6 \%)$, limonene $(5.4 \% ; 4.4 \%)$ and $\gamma$-terpinene $(3.5 \% ; 2.4 \%)$, totalizing more than $70 \%$ in the oils. The DPPH radical scavenging activity $\left(\mathrm{EC}_{50}, 16.7 \pm 0.4 \mu \mathrm{g} / \mathrm{mL}\right)$ of the methanol extract was comparable to BHT $(19.8 \pm 0.5 \mu \mathrm{g} / \mathrm{mL})$ showing a significant antioxidant activity. The oils showed low activities. The amount of total phenolics (TP, $373.0 \pm 15.9 \mathrm{mg} \mathrm{GAE} / \mathrm{g}$ ) and trolox equivalent (TEAC, $226.8 \pm 0.5 \mathrm{mg} \mathrm{TE} / \mathrm{g}$ ) confirmed the antioxidant activity of the methanol extract that can be attributed to the presence of polar phenolic compounds. In the brine shrimp bioassay the lethal concentrations $\left(\mathrm{LC}_{50}\right)$ for the oil and methanol extract were $6.7 \pm 0.2 \mu \mathrm{g} / \mathrm{mL}$ and $13.0 \pm 3.7 \mu \mathrm{g} / \mathrm{mL}$, respectively, providing important evidence of their biological activities.
\end{abstract}

Keywords: Hyptis crenata, Lamiaceae, salva-do-marajó, essential oil, antioxidant activity, total phenolic content, cytotoxicity.

\section{INTRODUCTION}

The genus Hyptis comprises nearly 400 species belonging to Lamiaceae and occurring in tropical America. The species Hyptis crenata Pohl ex Bentham is an annual herbaceous plant reaching $60-80 \mathrm{~cm}$ in height, growing spontaneously on sandy soil near streams in the Marajó Island, State of Pará, Brazil. The plant is known as "salva-do-marajó", "salsa-do-campo" or "hortelãdo-campo" and is used by the riverine communities as spices for food aromatization and anti-inflammatory medicine (Maia et al., 2001; Andrade et al., 2002).
Concerning the Hyptis species occurring in the Brazilian Amazon we previously analyzed the essential oil composition of $H$. suaveolens, $H$. mutabilis and $H$. goyazensis (Gottlieb et al., 1981; Luz et al., 1984 and 1989; Andrade et al., 2003). The essential oil of another specimen of $H$. crenata collected in the Brazilian Pantanal was first reported (Scramin et al., 2000).

Essential oils and plant extracts have been studied for their potential use as alternative dietary supplement to prevent infectious diseases and in the preservation of foods from the toxic effects of oxidants. The antioxidant properties of aromatic plants and spices 
have been indicated as effective in delaying the lipid peroxidation of foods (Bracco et al., 1981; Kramer, 1985; Lagouri et al., 1993; Souza et al., 2007). Tsimidou and Boskou (1994) observed that between the herbs and spices extensively studied, the plants belonging to the Lamiaceae family have significant antioxidant activity. In spite of the intensive investigation of the antioxidant activities of the European and Asian herbs and spices, little is known about the properties of these plants in South America (Stashenko et al., 2004; Sachettii et al., 2004; Costa et al., 2008; Sousa et al., 2008).

As part of an ongoing inventory of the Amazon odoriferous flora, including its herbs and spices, this study report the essential oil composition of a specimen of Hyptis crenata collected on the Marajó Island, PA, Brazil, as well as its antioxidant capacity, the total phenolic content and the cytotoxicity of the oils and methanol extract using the DPPH radical scavenging, the Folin-Ciocalteu reagent and the brine shrimp bioassay.

\section{MATERIAL AND METHODS}

\section{Plant material}

Samples of Hyptis crenata were collected in the locality of "Deus-me-ajude" (God, help me), Municipality of Salvaterra, Marajó Island, State of Pará, Brazil, in March 2005. The plant was identified by comparison with an authentic voucher of $H$. crenata (\#MG174699) that is deposited in the herbarium of Emílio Goeldi Museum, city of Belém, State of Pará, Brazil.

\section{Plant processing}

The plant material was separated in fresh and air-dried portions (150 g each) and submitted to hydrodistillation using a Clevenger-type apparatus (3 h). The hydrodistilled oils were dried over anhydrous sodium sulfate and the percentage content calculated on basis of the plant dry weight. The moisture content of samples was calculated after the aqueous phase separation using a Dean-Stark trap (5 g, $30 \mathrm{~min}$ ) and toluene. Similarly, the powdered air-dried sample was submitted to solvent extraction ( $75 \mathrm{~g}, 4 \mathrm{~h}$ ) using a Sohxlet extractor and methanol. The solvent was eliminated by vacuum evaporation and the yield was calculated. The oils were codified as $\mathrm{HcO}$ and $\mathrm{HcOd}$, and the methanol extract was codified as HcEd.

\section{Oil composition analysis}

The analysis of the volatile compounds was performed on a Finnigan Mat INCOS XL GC-MS instrument, with the following conditions: WCOT DB$5 \mathrm{~ms}(30 \mathrm{~m} \times 0.25 \mathrm{~mm} ; 0.25 \mu \mathrm{m}$ film thickness) fused silica capillary column; temperature programmed: 60 -

$240{ }^{\circ} \mathrm{C}\left(3{ }^{\circ} \mathrm{C} / \mathrm{min}\right)$; injector temperature: $220^{\circ} \mathrm{C}$; carrier gas: helium, adjusted to a linear velocity of $32 \mathrm{~cm} / \mathrm{s}$ (measured at $\left.100^{\circ} \mathrm{C}\right)$; injection type: splitless $(2 \mu \mathrm{L}$, of a 1:1000 hexane sol.); split flow was adjusted to give a 20:1 ratio; septum sweep was a constant $10 \mathrm{~mL} / \mathrm{min}$; EIMS: electron energy, $70 \mathrm{eV}$; ion source temperature and connection parts: $180{ }^{\circ} \mathrm{C}$. The quantitative data of the oils were obtained by peak area normalization using a HP 5890 GC/FID operated under the same GC-MS condition, except for the carrier gas that was hydrogen produced by a Packard hydrogen generator and a WCOT CP-Sil CB (25 m x $0.25 \mathrm{~mm} ; 0.25 \mu \mathrm{m}$ film thickness) fused silica capillary column. The individual components of oils were identified by comparison of both mass spectrum and their GC retention data with those of authentic compounds previously analyzed and stored in the data system. Additional identifications were made by comparison of mass spectra with those existing in the data system libraries and cited in the literature (Adams, 2007; NIST, 2005). The retention index was calculated for all volatiles constituents using an n-alkanes homologous series.

\section{Antioxidant capacity evaluation}

A stock solution of DPPH radical $(0.5 \mathrm{mM})$ in methanol was prepared. The solution was diluted in methanol $(60 \mu \mathrm{M}$ approx.) measuring an initial absorbance of $0.62 \pm 0.02$ in $517 \mathrm{~nm}$ at room temperature. The reaction mixture was composed by $1950 \mu \mathrm{L}$ of DPPH solution and $50 \mu \mathrm{L}$ of the samples diluted in different methanol portions. For each sample a methanol blank was also measured. The absorbance was measured in the reaction starting (time zero), every 5 min during the first $20 \mathrm{~min}$ and then at continuous intervals of $10 \mathrm{~min}$ up to constant absorbance. All experiments were triplicate. Trolox (6-hydroxy-2,5,7,8-tetramethylchroman-2carboxylic acid) and BHT (butylated hydroxytoluene) were used as standard antioxidants. The radical scavenging activity of each sample was calculated by the DPPH inhibition percentage according the Eq. (1):

$$
\mathrm{IP}_{\mathrm{DPPH}}=100(\mathrm{~A}-\mathrm{B}) / \mathrm{A},(1)
$$

where $\mathrm{A}$ and $\mathrm{B}$ are the blank and sample absorbance values in the end reaction. The radical scavenging activity, expressed as milligrams of trolox equivalent per gram of each sample, was also calculated by means of the Eq. (2):

$$
\begin{gathered}
\mathrm{TE}=(\mathrm{A}-\mathrm{B}) /(\mathrm{A}-\mathrm{C}) \times 25 / 1000 \times 250.29 / 1000 \times \\
1000 / 10 \times \mathrm{D},(2)
\end{gathered}
$$

where $\mathrm{A}, \mathrm{B}$ and $\mathrm{C}$ are the blank, sample and trolox absorbance values in the reaction end, and $\mathrm{D}$ is the dilution factor (Choi et al., 2000; Hu et al., 2004; Yamaguchi et al., 1998). The concentration of antioxidant required 
for $50 \%$ scavenging of DPPH radicals $\left(\mathrm{EC}_{50}\right)$ were determined by linear regression using Windows/Excel.

\section{Total phenolics evaluation}

The amount of total phenolics (TP) of methanol extract was determined according to the Folin-Ciocalteu procedure (Singleton and Rossi, 1965; Kähkönen et al., 1999). The experimental calibration curve was prepared using $500 \mu \mathrm{L}$ of aqueous solution of gallic acid mixed with $250 \mu \mathrm{L}$ of Folin-Ciocalteu reagent (1.0 $\mathrm{N})$ and $1250 \mu \mathrm{L}$ of sodium carbonate $(75 \mathrm{~g} / \mathrm{L})$ resulting in final gallic acid concentrations of $0.57,1.14,2.28$, $3.42,4.56,5.70$ and $6.84 \mathrm{mg} / \mathrm{L}$. The absorbance was measured after $30 \mathrm{~min}$ at $760 \mathrm{~nm}$ and $25^{\circ} \mathrm{C}$ (UV-Vis spectrophotometer, ULTROSPEC 2000). The methanol extract was dissolved in methanol $(2 \mathrm{mg} / \mathrm{mL})$, diluted in water (1:99) and submitted to the same procedure. The total phenolics content was expressed as gallic acid equivalents (GAE) in milligrams per gram of extract, using the Eq. (3):

$$
\operatorname{GAE}(\mathrm{mg} / \mathrm{L})=\mathrm{A} \times \mathrm{D} \times 7.93 \times \mathrm{d},(3)
$$

where $\mathrm{A}$ is the sample absorbance, $\mathrm{D}$ is the sample dilution, 7.93 is the angular coefficient, and $\mathrm{d}$ is the reaction dilution.

Table 1. Composition of volatiles identified in the oils of Hyptis crenata.

\begin{tabular}{|c|c|c|c|c|}
\hline No. & Components & $\mathrm{RI}^{\mathrm{a}}$ & $\operatorname{HcOf}(\%)^{b}$ & $\mathrm{CsOd}(\%)^{\mathrm{b}}$ \\
\hline 1 & $\alpha$-thujene & 930 & 0.6 & 0.5 \\
\hline 2 & $\alpha$-pinene & 939 & 22.0 & 19.5 \\
\hline 3 & camphene & 952 & 2.7 & 2.7 \\
\hline 4 & sabinene & 975 & 0.6 & 0.1 \\
\hline 5 & $\beta$-pinene & 979 & 17.0 & 13.8 \\
\hline 6 & myrcene & 990 & 1.6 & 1.3 \\
\hline 7 & $\alpha$-phellandrene & 1003 & 0.2 & 0.2 \\
\hline 8 & $\alpha$-terpinene & 1117 & 1.1 & 0.8 \\
\hline 9 & $p$-cymene & 1025 & 2.0 & 1.8 \\
\hline 10 & limonene & 1028 & 5.4 & 4.4 \\
\hline 11 & 1,8 -cineole & 1033 & 17.6 & 23.2 \\
\hline 12 & $\gamma$-terpinene & 1060 & 3.5 & 2.4 \\
\hline 13 & terpinolene & 1089 & 1.1 & 0.8 \\
\hline 14 & camphor & 1142 & 4.7 & 11.6 \\
\hline 15 & borneol & 1164 & 2.1 & 5.3 \\
\hline 16 & 4-terpineol & 1178 & 1.0 & 2.7 \\
\hline 17 & $\alpha$-terpineol & 1190 & - & 0.1 \\
\hline 18 & $\alpha$-longipinene & 1353 & 2.0 & 0.1 \\
\hline 19 & $\beta$-caryophyllene & 1419 & 1.0 & 0.6 \\
\hline 20 & aromadendrene & 1441 & - & 0.1 \\
\hline 21 & $\beta$-chamigrene & 1475 & 2.3 & 0.2 \\
\hline 22 & $\beta$-himachalene & 1499 & 1.3 & 0.2 \\
\hline 23 & himachalol & 1647 & 1.3 & 0.1 \\
\hline \multicolumn{3}{|c|}{ Total } & 91.1 & 92.5 \\
\hline
\end{tabular}

aRetention indices calculated for all volatile constituents using a homologous series of $n$-alkanes. ${ }^{b}$ Percentages are the mean of three runs and were obtained from FID electronic integration. 
Table 2. Data of antioxidant capacity for the plant oils and methanol extract of Hyptis crenata.

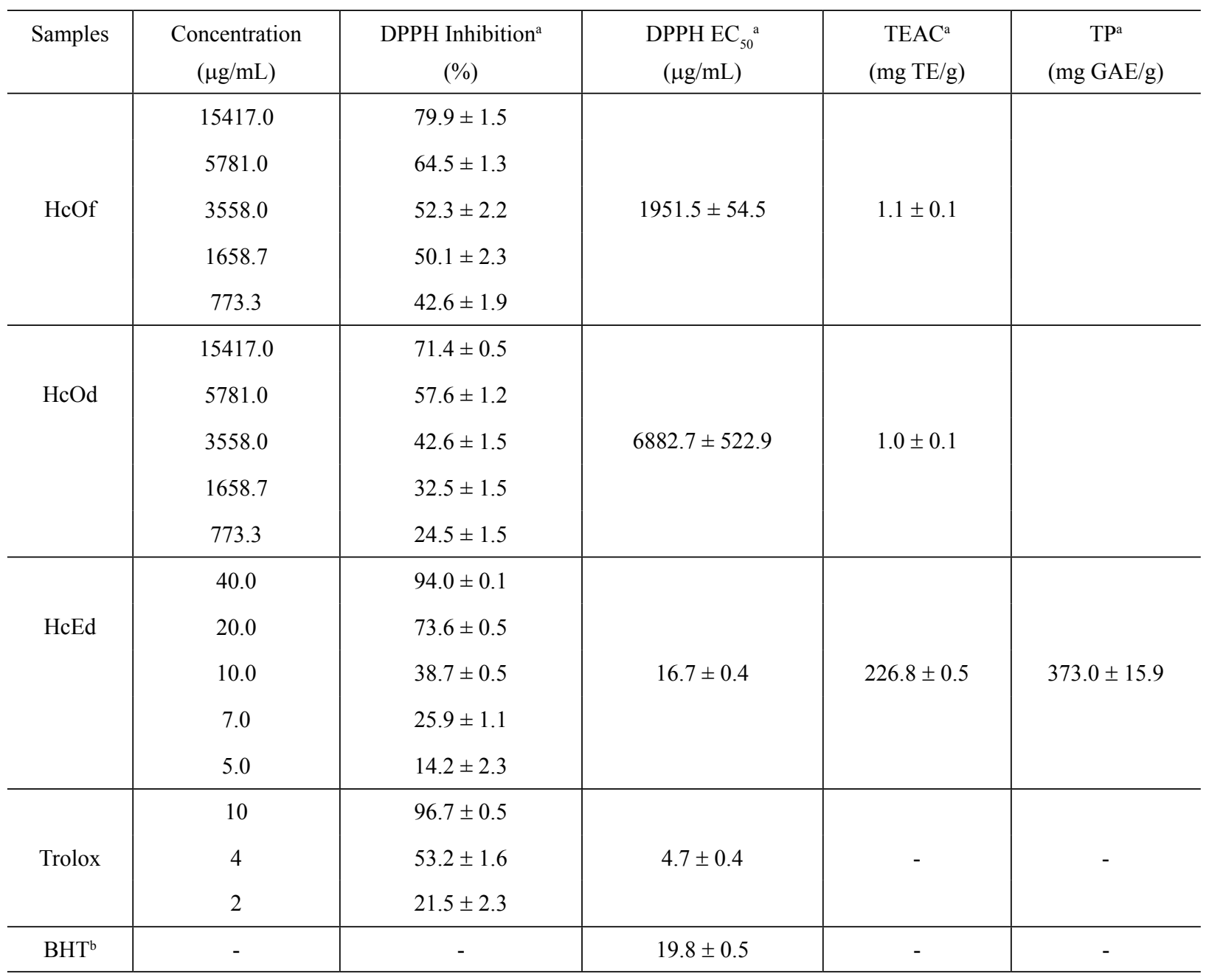

${ }^{\mathrm{a}}$ Mean \pm standard deviation, ${ }^{\mathrm{b}}$ Literature data.

Table 3. Lethal concentration of oil and methanol extract of Hyptis crenata for the brine shrimp bioassay.

\begin{tabular}{|c|c|c|c|}
\hline Samples & $\begin{array}{l}\text { Concentration } \\
\qquad(\mu \mathrm{g} / \mathrm{mL})\end{array}$ & $\begin{array}{c}\text { Mortality } \\
(\%)\end{array}$ & $\begin{array}{c}\mathrm{LC}_{50} \\
(\mu \mathrm{g} / \mathrm{mL})\end{array}$ \\
\hline \multirow{4}{*}{ HcOf } & 1 & 0,0 & \multirow{4}{*}{$6.7 \pm 0.2$} \\
\hline & 5 & 40.0 & \\
\hline & 10 & 60.0 & \\
\hline & 25 & 100.0 & \\
\hline \multirow{6}{*}{ HcEd } & 1.0 & 10.0 & \multirow{6}{*}{$13.0 \pm 3.7$} \\
\hline & 10.0 & 46.7 & \\
\hline & 25.0 & 56.7 & \\
\hline & 50.0 & 80.0 & \\
\hline & 100.0 & 86.7 & \\
\hline & 500.0 & 95.0 & \\
\hline
\end{tabular}




\section{Brine shrimp bioassay}

Brine shrimp lethality bioassay was carried out to investigate the cytotoxicity (biological activity) of the oils and extract (Meyer et al., 1982; Lewan et al., 1992). Brine shrimps (Artemia salina) were hatched using brine shrimp eggs in a glass rectangular vessel $(5 \mathrm{~L})$, filled with sterile artificial seawater, prepared using water $(2 \mathrm{~L}), \mathrm{NaCl}(46 \mathrm{~g}), \mathrm{MgCl}_{2} \cdot 6 \mathrm{H}_{2} \mathrm{O}(22 \mathrm{~g})$, $\mathrm{Na}_{2} \mathrm{SO}_{4}(8 \mathrm{~g}), \mathrm{CaCl}_{2} \cdot 2 \mathrm{H}_{2} \mathrm{O}(2.6 \mathrm{~g})$ and $\mathrm{KCl}(1.4 \mathrm{~g})$, with pH 9.0 adjusted with $\mathrm{Na}_{2} \mathrm{CO}_{3}$ under constant aeration for $48 \mathrm{~h}$. After hatching active nauplii free from egg shells were collected from brighter portion of the hatching chamber and used for the assay. Ten nauplii were drawn through a glass capillary and placed in vials containing $5 \mathrm{~mL}$ of brine solution. In each experiment the oil $(1 \%)$ and extract $(5 \%)$ solutions were prepared using the brine solution and DMSO. From these oil and extract solutions four other solutions at different concentrations were prepared and then added to the 5 $\mathrm{mL}$ brine solution. The vials were maintained at room temperature for $24 \mathrm{~h}$ under the light and the surviving larvae were counted. Experiments were conducted along with control and different concentrations (1, 10, 100 and $1000 \mu \mathrm{g} / \mathrm{mL}$ ) in a set of three tubes per dose. The percentage lethality was determined by comparing the mean value of surviving larvae of the test and the control tubes. Lethal concentration $\left(\mathrm{LC}_{50}\right)$ values were obtained from the best-fit line plotting concentration versus percentage lethality (Finney, 1971).

\section{RESULTS AND DISCUSSION}

The fresh (HcOf) and dried (HcOd) leaves and fine stems of $H$. crenata provided oil yields of $1.4 \%$ and $0.9 \%$, respectively. The oil yield of the dried plant ( $\mathrm{HcOd}, 0.9 \%)$ was equal to that before reported by us (Zoghbi et al., 2002). The oil yield of the fresh plant (HcOf, 1.4\%) was greater and it was determined by the first time. At the same time, the chemical composition of the oil was similar to that of our previous analysis using plants collected on Marajó Island, Brazil (Zoghbi et al., 2002). For the present analyses the main constituents of fresh and dried plants were $\alpha$-pinene $(22.0 \%$ and $19.5 \%)$, 1,8 -cineole $(17.6 \%$ and $23.2 \%), \beta$-pinene $(17.0 \%$ and $13.8 \%$ ), camphor $(4.7 \%$ and $11.6 \%)$, limonene $(5.4 \%$ and $4.4 \%)$ and $\gamma$-terpinene (3.5\% and $2.4 \%$ ), totalizing over $70 \%$ in the oils. The volatiles constituents identified in the oils of $H$. crenata are listed in Table 1.

The oils of $H$. crenata ( $\mathrm{HcOf}$ and $\mathrm{HcOd}$ ) were tested at high concentration, between 773.5 and 15417.0 $\mu \mathrm{g} / \mathrm{mL}$, to determine the DPPH scavenging activities. The kinetic reaction was slow with an average of 180 min. The resulting DPPH inhibition percent varied from $42.6 \%$ to $79.9 \%$ in the fresh oil (HcOf) and from $24.5 \%$ to $71.4 \%$ in the dried oil ( $\mathrm{HcOd})$ showing low antioxidant activities. On the other hand the methanol extract of dried plant (HcEd) was assayed at low concentrations, between 5 and $40 \mu \mathrm{g} / \mathrm{mL}$, to determine the DPPH scavenging activities. The kinetic reaction was slow in all tested concentration with an average of 120 min. The resulting DPPH inhibition percent ranged from $14.2 \%$ to $94.0 \%$ in the dried plant extract (HcEd) indicating a significant antioxidant property.

The $\mathrm{EC}_{50}$ values for the plant oils (HcOf: $1951.5 \pm 54.5 \mu \mathrm{g} / \mathrm{ml}$; HcOd: 6882.7. $\pm 522.9 \mu \mathrm{g} / \mathrm{mL}$ ), defined as the concentration of antioxidant required for $50 \%$ scavenging of DPPH radicals, were very high, confirming that the oils do not have important antioxidant activity. Choi et al. (2000) has reported that the monoterpenes $\gamma$-terpinene and terpinolene showed a DPPH radical-scavenging effect three times stronger than the trolox $(4.7 \pm 0.4 \mu \mathrm{g} / \mathrm{mL})$, while others, such as $\alpha$-pinene, $\beta$-pinene and 1,8-cineole did not show significant antioxidant capacity. The percentage of $\gamma$-terpinene and terpinolene in the analyzed oils is very small and thus with low contribution to their antioxidant activity. On the other hand, the $\mathrm{EC}_{50}$ value obtained for the dried methanol extract (HcEd: $16.7 \pm 0.4 \mu \mathrm{g} / \mathrm{mL}$ ) is comparable with that of butylated hydroxytoluene (BHT, $19.8 \pm 0.5 \mu \mathrm{g} / \mathrm{mL}$ ) (Sökmen et al., 2004), a commercial synthetic antioxidant, showing that it has a very strong antioxidant activity.

The amount of total phenolics (TP, $373.0 \pm$ $15.9 \mathrm{mg} \mathrm{GAE} / \mathrm{g}$ ) and trolox equivalent (TEAC, 226.8 $\pm 0.5 \mathrm{mg} \mathrm{TE} / \mathrm{g}$ ) for the dried methanol extract $(\mathrm{HcEd})$ confirmed the significant antioxidant activity of $H$. crenata that could be attributed to the presence of polar phenolic compounds.

The data of DPPH inhibition, DPPH radical activity $\left(\mathrm{EC}_{50}\right)$, trolox equivalent antioxidant capacity (TEAC) and total phenolics (TP) for the plant oils and methanol extract of $H$. crenata are shown in Table 2.

For the brine shrimp bioassay performed with the plant oil (HcOf) and methanol extract (HcEd) the lethal concentration $\left(\mathrm{LC}_{50}\right)$ was $6.7 \pm 0.2 \mu \mathrm{g} / \mathrm{ml}$ and $13.0 \pm 3.7$ $\mu \mathrm{g} / \mathrm{mL}$, respectively, showing a significant cytotoxicity where the oil was twice higher than the methanol extract. Oils and extracts from plants presenting lethal concentration values below $1000 \mu \mathrm{g} / \mathrm{mL}$ are considered as bioactive (Meyer et al., 1982). The data for brine shrimp bioassay are shown in Table 3 .

\section{ACKNOWLEDGMENTS}

The authors are grateful to Biodiversity Program (PPBio), Ministry of Science and Technology (MCT/ $\mathrm{CNPq}$ ), Brazilian Government, for financial support.

\section{REFERENCES}

Adams RP 2007. Identification of Essential Oil Components by Gas Chromatography/Mass Spectrometry. Carol Stream, Illinois: Allured Publishing Corporation. 
Andrade EHA, Ribeiro AF, Silva MHL, Zoghbi MGB, Maia JGS 2002. Plantas medicinais aromáticas usadas pela população ribeirinha. In Lisboa, P. L. B. (org.) Caxiuanã: populações tradicionais, meio físico $e$ diversidade biológica, (pp.421-431). Belém: Museu Paraense Emílio Goeldi.

Andrade EHA, Zoghbi MGB, Silva MHL, Maia JGS, Amasifén JMR, Rojas UM 2003. Chemical variation in the essential oil of Hyptis mutabilis (Rich.) Briq. $J$ Essent Oil Res 15: 130-132.

Bracco U, Loliger J, Viret J 1981. Production and use of natural antioxidant. J Am Oil Chem Soc 58: 686-690.

Choi HS, Song HS, Ukeda H, Sawamura M 2000. Radical scavenging activities of Citrus essential oils and their components: detection using 1,1-diphenyl-2picrylhydrazyl. J Agric Food Chem 48: 4156-4161.

Costa VCO, Tavares JF, Agra MF, Falcão-Silva VS, Facanali R, Vieira MAR, Marques MOM, Siqueira-Júnior JP, Silva MS 2008. Composição química e modulação da resistência bacteriana a drogas do óleo essencial das folhas de Rollinia leptopetala R. E. Fries. Rev Bras Farmacogn 18: 245-248.

Finney DJ, 1971. Probits analysis. Cambridge: Cambridge University Press.

Gottlieb OR, Koketsu M, Magalhães MT, Maia JGS, Mendes PH, Rocha AI, Silva ML, Wilberg VC 1981. Óleos essenciais da Amazônia. VII. Acta Amazonica 11: 143-148.

$\mathrm{Hu} \mathrm{Q}, \mathrm{Xu}$ J, Chen S, Yang F 2004. Antioxidant activity of extracts of black sesame seed (Sesamum indicum L.) by supercritical carbon dioxide extraction. J Agric Food Chem 52: 43-947.

Kähkönen MP, Hopia AI, Vuorela HJ, Rauha JP, Pihlaja K, Kujala TS, Heinonen M 1999. Antioxidant activity of plant extracts containing phenolic compounds. $J$ Agric Food Chem 47: 3954-3962.

Kramer RE 1985. Antioxidants in clove. J Am Oil Chem Soc 62: 111-113.

Lagouri V, Blekas G, Tsimidou M, Kokkini S, Boskou D 1993. Composition and antioxidant activity of essential oil from oregano plants grown in Greece. Z LebensmUnters-Forsch 197: 20-23.

Lewan L, Anderson M, Morales-Gomez P 1992. The use of Artemia salina in toxicity test. Alternat Lab Animals 20: 297-301.

Luz AIR, Zoghbi MGB, Ramos LS, Maia JGS, Silva ML 1984. Essential oils of some Amazonian Labiatae. 1. Genus Hyptis. J Nat Prod 47: 745-747.

Luz AIR, Zoghbi MGB, Silva ML, Ramos LS, Maia JGS 1989. Variedades químicas de Hyptis mutabilis. Acta Amazonica 19: 365-370.

Maia JGS, Zoghbi MGB, Andrade EHA 2001. Plantas Aromáticas da Amazônia e Seus Óleos Essenciais, Belém: Museu Paraense Emílio Goeldi.

Meyer BN, Ferrigni NR, Putnam JE, Jacobsen LB, Nichols DE, McLaughlin JL 1982. Brine shrimp: a convenient general bioassay for active plant constituents. Planta Med 45: 31-34.

NIST 2005. Mass Spectral Library. NIST Mass Spectral Search Program (NIST 05, Version 2.0d). Gaithersburg, MD.: The NIST Mass Spectrometry Data Center.

Sachettii G, Medici A, Maietti S, Radice M, Muzzoli M, Manfredini S, Braccioli E, Bruni R 2004.
Composition and functional properties of the essential oil of amazonian basil, Ocimum micranthum Willd., Labiatae, in comparison with commercial essential oils. J Agric Food Chem 52: 3486-3491.

Scramin S, Saito ML, Pott A, Marques MOM 2000. Volatile constituents of Hyptis crenata Pohl (Labiatae) native in Brazilian Pantanal. J Essent Oil Res 12: 99-101.

Singleton VL, Rossi JA 1965. Colorimetry of total phenolics with phosphomolybdic phosphotungstic acid reagents. Am J Enol Viticult 16: 144-158.

Sökmen M, Serkedjieva J, Daferera D, Gulluce M, Polissiou M, Tepe B, Akpulat A, Sahin F, Sökmen A 2004. In vitro antioxidant, antimicrobial, and antiviral activities of the essential oil and various extracts from herbal parts and callus cultures of Origanum acutidens. J Agric Food Chem 52: 3309-3311.

Sousa PJC, Barros CAL, Rocha JCS, Lira DS, Monteiro GM, Maia JGS 2008. Avaliação toxicológica do óleo essencial de Piper aduncum L. Rev Bras Farmacogn 18: 217-221.

Souza TJT, Apel MA, Bordignon S, Matzenbacher NI, Zuanazzi JAS, Henriques AT 2007. Composição química e atividade antioxidante do óleo volátil de Eupatorium polystachyum DC. Rev Bras Farmacogn 17: 368-372.

Stashenko EE, Jaramillo BE, Martinez JR 2004. Comparison of different extraction methods for the analysis of volatile secondary metabolites of Lippia alba (Mill.) N. E. Brown, grown in Colombia, and evaluation of its in vitro antioxidant activity. $J$ Chromatogr $A$ 1025: 93-103.

Tsimidou M, Boskou D 1994. Antioxidant activities of essential oils from the plants of the Lamiaceae family. In G. Charalambous, Spices, herbs and edible fungi, Amsterdam: Elsevier. Dev Food Sci 34: 273284.

Yamaguchi T, Takamura H, Matoba T, Terao J 1998. HPLC method for evaluation of free radical-scavenging activity of foods by using 1,1-diphenyl-2picrylhydrazyl. Biosci Biotech Biochem 62: 12011204.

Zoghbi MGB, Andrade EHA, Silva MHL, Maia JGS, Luz AIR, Silva JD 2002. Chemical variation in the essential oils of Hyptis crenata Pohl ex Benth. Flav Fragr J 17: 5-8. 